ISSN 2089-8673

Jurnal Nasional Pendidikan Teknik Informatika (JANAPATI)

Volume 2, Nomor 1, Maret 2013

\title{
PENGEMBANGAN APLIKASI CITRA DIGITAL UNTUK MENGUBAH CITRA GREYSCALE MENJADI CITRA BERWARNA
}

\section{Md Agus Wirahadi P, Made Windu Antara Kesiman, Dessy Seri Wahyuni Jurusan Pendidikan Teknik Informatika Universitas Pendidikan Ganesha}

Email: wirahadi335@gmail.com, dekndu@yahoo.com

\begin{abstract}
ABSTRAK
Penelitian ini bertujuan untuk merancang dan mengembangkan sebuah aplikasi pewarnaan citra greyscale secara otomatis, dengan mengimplementasikan algoritma Global Image Matching. Inputan dari aplikasi ini adalah citra yang berekstensi bitmap (*.bmp). Terdapat 2 macam pilihan pewarnaan citra greyscale yaitu colorization dan image sequences. Kedua pemrosesan tersebut memiliki perbedaan pada jumlah citra input dan citra output. Pada colorization, citra input yang digunakan adalah 1 buah citra greyscale dan 1 buah citra warna dan akan menghasilkan 1 buah citra output sedangkan pada image sequences menggunakan 1 buah citra greyscale dan 3 buah citra warna dimana pada pemrosesan ini akan menghasilkan 12 citra output. Berdasarkan hasil pengujian, aplikasi pewarnaan citra greyscale mampu melakukan proses pewarnaan citra greyscale secara mudah. Perangkat lunak aplikasi pewarnaan citra greyscale dikembangkan dengan menggunakan bahasa pemrograman Delphi 2010.
\end{abstract}

Kata Kunci : Citra Digital, Global Image Matching, Colorization, Image Sequences. 
ISSN 2089-8673

Jurnal Nasional Pendidikan Teknik Informatika (JANAPATI)

Volume 2, Nomor 1, Maret 2013

\section{PENDAHULUAN}

Persepsi visual citra berwarna (color image) umumnya lebih kaya dibandingkan dengan citra skala keabuan (image Greyscale). Warna dalam citra merupakan "powerful descriptor" dimana sebuah warna sering digunakan dalam penyederhanaan pengenalan objek dan ekstraksi dari suatu objek. Selain itu, dalam warna terkandung informasiinformasi khusus sehingga tanpa adanya warna yang jelas, terkadang seseorang dapat salah dalam menginterpretasikan suatu objek di dalam suatu citra.

Citra yang memiliki warna greyscale cenderung kurang menarik utuk dilihat dibandingkan dengan citra berwarna., karena kamera pada jaman dahulu hanya mampu menghasilkan citra dengan format warna greyscale, sehingga hasil citra tersebut menjadi kurang menarik untuk dilihat. Padahal, banyak citra zaman dahulu memiliki nilai sejarah yang cukup tinggi yang semestinya disampaikan dari generasi kegenerasi.

Dalam mewarnai citra greyscale dibutuhkan waktu yang cukup lama serta biaya yang tidak sedikit, karena dalam proses pewarnaan citra greysacale menjadi citra berwarna, dibutuhkan seseorang yang ahli dalam bidang seni dan desain grafis. Berdasarkan permasalahan tersebut perlu dikembangkannya suatu aplikasi yang dapat membuat citra dengan format greyscale tersebut menjadi berwarna, sehingga dapat mengurangi beban biaya serta waktu yang dibutuhkan dan juga dapat dilakukan oleh orang awam.

\section{METODOLOGI}

\subsection{Global Image Matching}

Transfer warna dari citra warna ke dalam citra Greyscale dilakukan dengan mencocokkan tingkat kecerahan dan tekstur diantara dua gambar (Primoze, 2002). Teknik yang digunakan dalam pentransferan warna dari citra warna ke dalam citra greyscale adalah teknik "Global Image Matching” dimana dalam metode ini campur tangan manusia sangat sedikit, selain itu dalam proses pentransferan warna dengan menggunakan teknik Global Image Matching dibutuhkan beberapa tahapan yang harus dilakukan. Berikut adalah penjelasan dari tahapan-tahapan tersebut (Dewi, 2003). 
ISSN 2089-8673

Jurnal Nasional Pendidikan Teknik Informatika (JANAPATI)

Volume 2, Nomor 1, Maret 2013

\subsubsection{Merubah Ruang Warna RGB ke dalam Ruang Warna $l \alpha \beta$}

Ruang warna $l \alpha \beta$ merupakan ruang warna yang dikembangkan oleh Ruderman. Ruang warna ini memiliki 3 buah channel dimana $l$ merupakan luminance, komponen $\alpha$ merupakan komponen penyusun warna yaitu dari kuning sampai biru dan komponen $\beta$ merupakan komponen penyusun warna yaitu dari merah sampai dengan hijau. Cara untuk mengubah citra dengan ruang warna RGB menjadi citra dengan ruang warna $l \alpha \beta$, dapat menggunakan matriks konversi sebagai berikut:

$$
\begin{aligned}
& \begin{array}{lll}
0.3811 & 0.5783 & 0.0402
\end{array} \\
& \begin{array}{lll}
0.1967 & 0.7244 & 0.0782
\end{array} \\
& \begin{array}{llll}
0.0241 & 0.1288 & 0.8444
\end{array} \\
& \begin{array}{ccccccc}
1 & \frac{1}{\sqrt{3}} & 0 & 0 & & & \\
& 0 & \frac{1}{\sqrt{6}} & 0 & 1 & 1 & 2 \\
& 0 & 0 & \frac{1}{\sqrt{2}} & & &
\end{array}
\end{aligned}
$$

\subsubsection{Penyesuaian Tingkat Kecerahan Warna}

Citra warna dan citra greyscale memiliki perbedaan tingkat kecerahan yang cukup tinggi, hal ini dapat berpengaruh di dalam proses pewarnaan sehingga diperlukan adanya suatu proses luminance remapping, yaitu suatu proses menggeser dan menskalakan tingkat kecerahan citra warna agar sesuai dengan tingkat kecerahan citra greyscale (Dewi,2003). Terdapat beberapa tahapan dalam melaksanakan proses penyesuain tingkat kecerahan citra, adapun tapan tersebut adalah sebagai berikut:

a. Membuat histogram tingkat kecerahan gambar warna

b. Membuat histogram tingkat kecerahan gambar greyscale

c. Melakukan proses luminance remapping

\subsubsection{Menghitung Statistik Pixel}

Proses ini bertujuan untuk mencari kecocokkan antara citra warna dengan citra greyscale. Terdapat beberapa tahapan yang harus dilakukan untuk mencari kecocokkan antara citra warna dengan citra greyscale yaitu 
ISSN 2089-8673

Jurnal Nasional Pendidikan Teknik Informatika (JANAPATI)

Volume 2, Nomor 1, Maret 2013

a. Pemilihan sampel pixel warna pada citra warna

Sampel warna merupakan contoh pixel warna yang nantinya akan diambil nilai comatik warnanya yang akan digunakan sebagai pigmen warna pixel pada citra greyscale. Penggunaan sampel warna juga bertujuan untuk mengurangi jumlah pembanding sampel warna, sehingga dapat mempercepat proses.

b. Perhitungan statistik

Perhitungan statistik yang dimaksud disini adalah perhitungan mean (rata-rata) dan perhitungan standar deviasi (simpangan baku). Perhitungan statistik dilakukan pada kedua citra inputan. Pada citra warna, perhitungan dilakukan pada masing-masing sampel sedangkan pada citra greyscale dilakukan pada keseluruhan masing-masing pixel. Dalam perhitungan nilai rata-rata dan simpangan baku setiap pixel dilakukan dengan menggunakan matriks 5 X 5 .

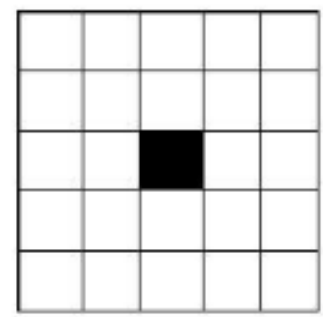

Gambar 1. Gambar Pixsel 5 X 5

\subsubsection{Mencocokan Pixel}

Setiap pixel pada citra greyscale dicocokkan dengan pixel sampel yang didapat dari citra warna. Proses pencocokan dilakukan dengan menghitung bobot rata-rata dan simpangan baku di sekelilingnya. 
ISSN 2089-8673

Jurnal Nasional Pendidikan Teknik Informatika (JANAPATI)

Volume 2, Nomor 1, Maret 2013

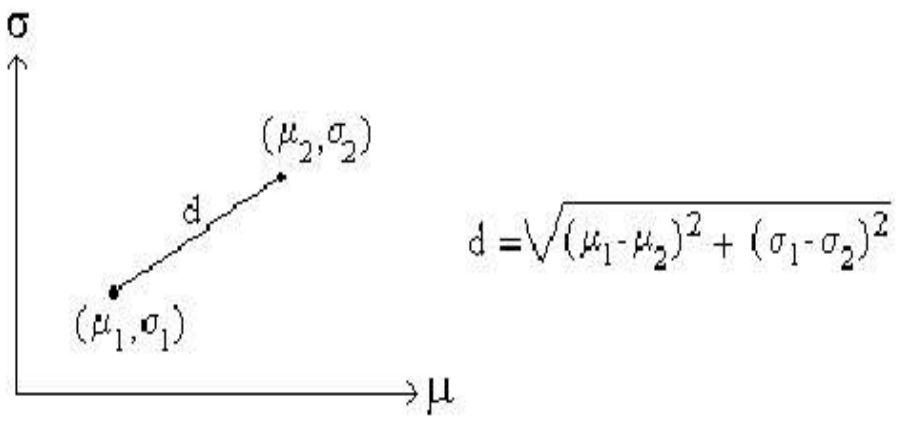

Gambar 2. Pencocokan Mean dan Standar Deviasi Citra Greyscale Dan Citra Warna (Dewi, 2003)

\subsubsection{Pewarnaan Citra Greyscale}

Untuk merubah citra dengan ruang warna $l \alpha \beta$ ke dalam ruang warna RGB dibutuhkan matriks konversi

$$
\begin{array}{cccccc} 
& & & \frac{\sqrt{3}}{3} & 0 & 0 \\
1 & 1 & 1 & & \sqrt{6} & \\
1 & 1 & 1 & 0 & \frac{1}{6} & 0 \\
1 & 2 & 0 & & & \sqrt{2} \\
& & & 0 & 0 & \frac{1}{2}
\end{array}
$$

$\begin{array}{ccc}4.4679 & 3.5873 & 0.1193 \\ 1.2186 & 2.3809 & 0.1624 \\ 0.0497 & 0.2439 & 1.2045\end{array}$

\subsection{Blending}

Blending merupakan penggabuangan dua buah citra menjadi satu citra, dengan kata lain dilakukan operasi penjumlahan terhadap citra yang ada dengan pemberian bobot pada masing-masing citra

$$
\mathrm{C}(\mathrm{x}, \mathrm{y})=\mathrm{wa} * \mathrm{~A}(\mathrm{x}, \mathrm{y})+\mathrm{wb} * \mathrm{~B}(\mathrm{x}, \mathrm{y})
$$

(Putra, 2010)

Wa dan wb adalah bobot untuk citra $\mathrm{A}$ dan $\mathrm{B}$, dan nilai jumlah total dari bobot adalah 1. 
ISSN 2089-8673

Jurnal Nasional Pendidikan Teknik Informatika (JANAPATI)

Volume 2, Nomor 1, Maret 2013

\subsection{Analisis Masalah dan Usulan Solusi}

Berdasarkan analisis dari proses pewarnaan citra greyscale sebelumnya, terdapat kelemahan-kelemahan dalam proses pewarnaan citra greyscale. Adapun permasalahannya adalah sebagai berikut

a. Dalam proses pewarnaan citra greyscale menjadi citra berwarna sebelumnya masih menggunakan cara yang konvensional dimana proses ini dilakukan dengan proses pewarnaan menggunakan kuas serta cat. Sehingga membutuhkan seseorang yang ahli dalam bidang lukis. Selain menggunakan cara konvensional proses pewarnaan juga dapat dilakukan dengan bantuan komputer. Software yang digunakan biasanya merupakan software khusus desain grafis sehingga membutuhkan seseorang yang ahli dalam bidang desain grafis.

b. Membutuhkan orang yang ahli dalam bidang desain grafis dan seni serta memerlukan waktu yang cukup lama dan biaya yang tidak sedikit.

c. Tidak adanya variasi citra output dari aplikasi pewarnaan citra greyscale pada aplikasi sebelumnya.

Berdasarkan analisis masalah di atas, solusi yang dapat diusulkan adalah sebuah perangkat lunak aplikasi pewarnaan citra greyscale menjadi citra berwarna. Adapun solusi yang ditawarkan pada aplikasi adalah:

a. Proses pewarnaan citra greyscale dapat ditangani langsung oleh sistem secara otomatis dengan meminimalisir bantuan user. Sehingga dengan demikian proses pewarnaan citra greyscale dapat dilakukan oleh orang awam. Karena dapat dilakukan oleh orang awam maka biaya serta waktu pembuatan dapat diminimalisir.

b. Dengan menggunakan 3 buah citra acuan (citra warna) maka akan menghasilkan 3 buah citra output dengan variasi warna yang berbeda yang kemudian akan mengalami proses blending sehingga akan menghasilkan 12 citra output. 
ISSN 2089-8673

Jurnal Nasional Pendidikan Teknik Informatika (JANAPATI)

Volume 2, Nomor 1, Maret 2013

\subsection{Analisis Perangkat Lunak}

Berdasarkan analisis terhadap pengembangan aplikasi pewarnaan citra greyscale, terdapat beberapa proses yang dapat diimplementasikan, yaitu :

a. Melakukan operasi perubahan ruang warna dari ruang warna RGB ke dalam ruang warna $l \alpha \beta$ dan juga sebaliknya dari ruang warna $l \alpha \beta$ ke ruang warna RGB

b. Melakukan operasi penyesuaian tingkat kecerahan gambar. Penyesuaian tingkat kecerahan kedua gambar dilakukan dengan dua pemerosesan yaitu dengan terlebih dahulu melakukan histogram equalization dan diteruskan ke proses luminance remapping.

c. Melakukan operasi statistika, yaitu mencari mean dan standar deviasi terhadap masing-masing citra inputan.

d. Melakukan operasi pencocokan nilai pixel. Pencocokan nilai pixel didasarkan atas nilai perhitungan pada operasi statistik.

e. Melakukan proses pewarnaan. Pada proses ini pixel-pixel yang sudah dicocokan maka akan ditransfer ke nilai kromatik pada citra gryscale dengan tetap mempertahan nilai luminance dari citra greyscale.

f. Melakukan proses blending citra output untuk menghasilkan citra output yang memiliki variasi warna.

Keenam proses tersebut merupakan gambaran umum dari perangkat lunak yang akan dibangun

\subsection{Perancangan Perangkat Lunak}

Perancangan perangkat lunak aplikasi pewarnaan citra greyscale memiliki 2 pilihan proses pewarnaan yaitu colorization dan image sequences dimana kedua proses tersebut memiliki perbedaan pada jumlah citra yang diinputkan dan juga citra yang dihasilkan. Pada pemrosesan colorization, user hanya menginputkan 1 buah citra greyscale dan satu buah citra warna sehingga hanya menghasilkan 1 buah citra output sedangkan pada pemrosesan image sequences menggunakan 1 buah citra greyscale dan 3 buah citra warna. Pada pemrosesan image sequences menghasilkan 3 buah citra 
ISSN 2089-8673

Jurnal Nasional Pendidikan Teknik Informatika (JANAPATI)

Volume 2, Nomor 1, Maret 2013

greyscale yang kemudian mengalami proses blending sehingga menghasilkan 12 citra output. Berikut merupakan arsitektur perangkat lunak yang akan dibangun

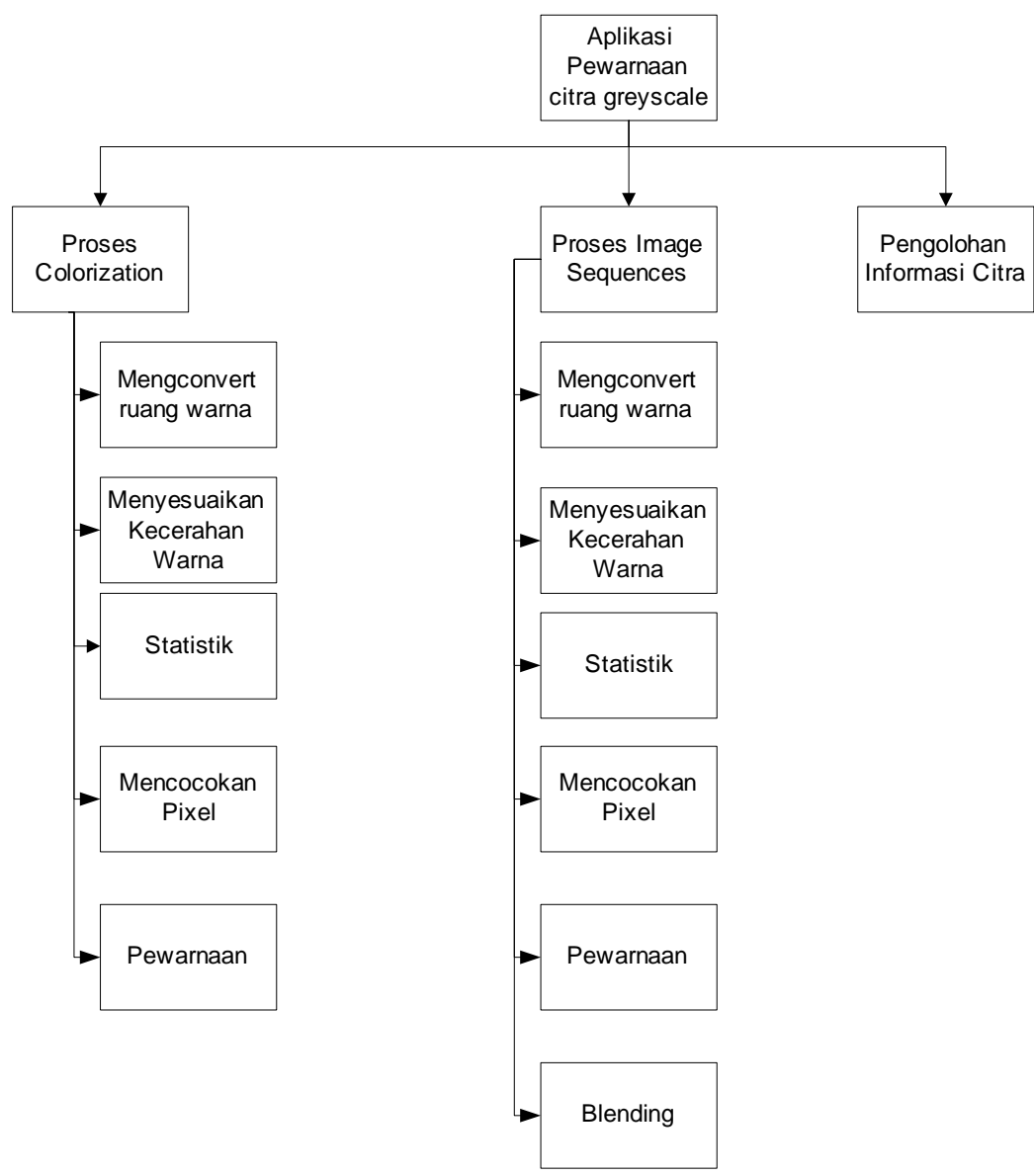

Gambar 3. Structure Chart Perangkat Lunak Aplikasi Pewarnaan citra greyscale

\section{Pembahasan}

\subsection{Implementasi Perangkat Lunak Pewarnaan Citra Greyscale}

Data Flow Diagram (DFD) dan Structure Chart perangkat lunak aplikasi pewarnaan citra greyscale diimplementasikan menggunakan bahasa pemrograman Delphi 2010. Berikut ini pemetaan unit serta tampilan form utama dari aplikasi pewarnaan citra greyscale. 


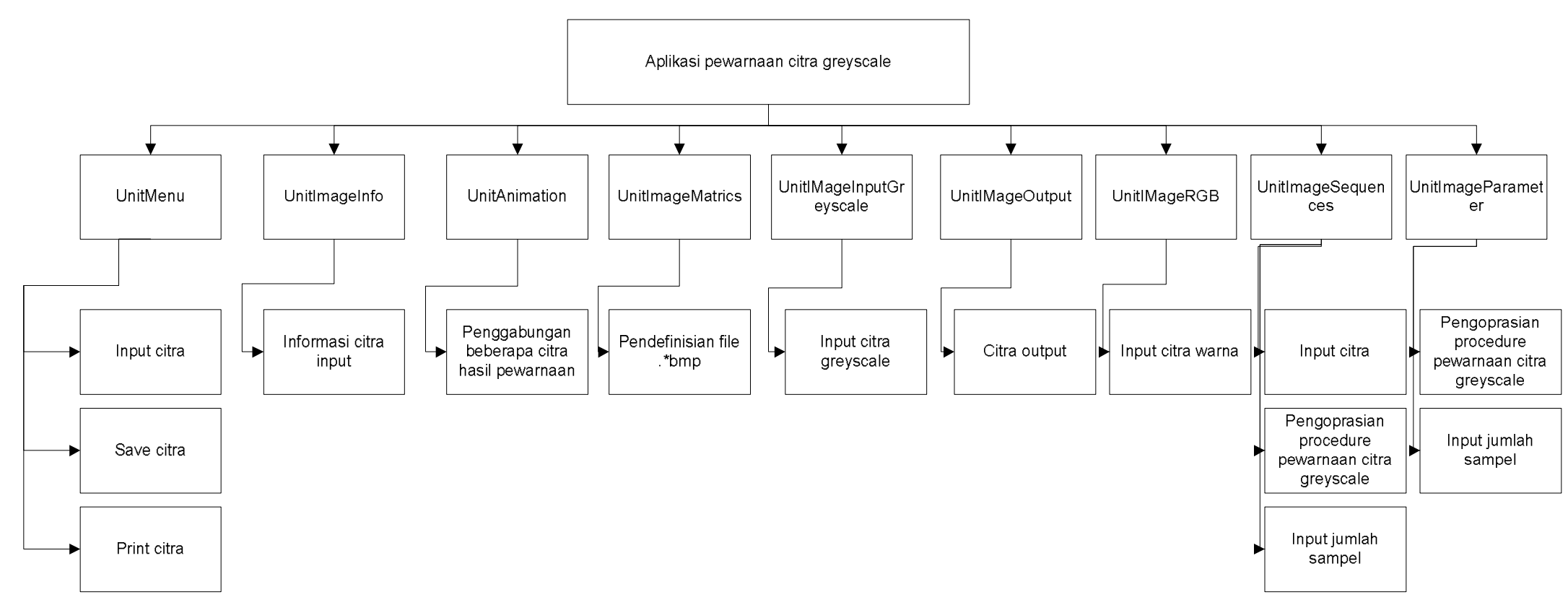

Gambar 4. Pemetaan Unit Aplikasi Pewarnaan Citra Greyscale 


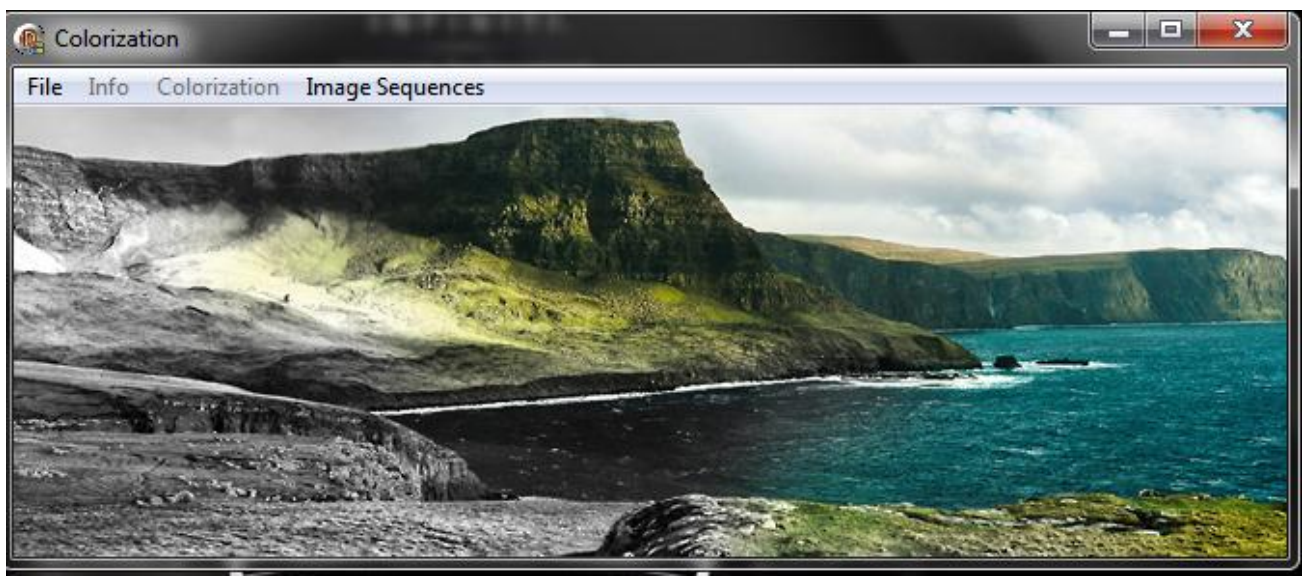

Gambar 5. Form Menu Utama

\subsection{Pengujian Perangkat Lunak Pewarnaan Citra Greyscale}

Secara umum hasil pengujian fungsional menunjukan bahwa sistem sudah dapat menangani data masukan yang tidak valid dan dapat melakukan proses pewarnaan citra greyscale disetiap proses dengan baik. Hasil pengujian koseptual menunjukan bahwa sistem telah melaksanakan algoritma Global Image Matching sesuai dengan apa yang diharapkan.

\subsubsection{Pengujian Colorization}

Pengujian colorization menggunakan 2 buah citar inputan,yaitu citra warna sebagai sumber warna dan citra greyscale sebagai citra yang akan mengalami proses pewarnaan. Proses colorization menggunakan 3 buah form yaitu form parameter, form image greyscale, dan form input color. Form parameter berperan sebagai unit kontrol dimana pada form parameter, user menginputkan jumlah sampel yang akan digunakan. Jumlah sampel yang dimaksud disini adalah banyaknya contoh-contoh pixel warna yang diabil dari citra warna yang akan digunakan di dalam proses colorization. Form parameter ditunjukan pada gambar 6 . 


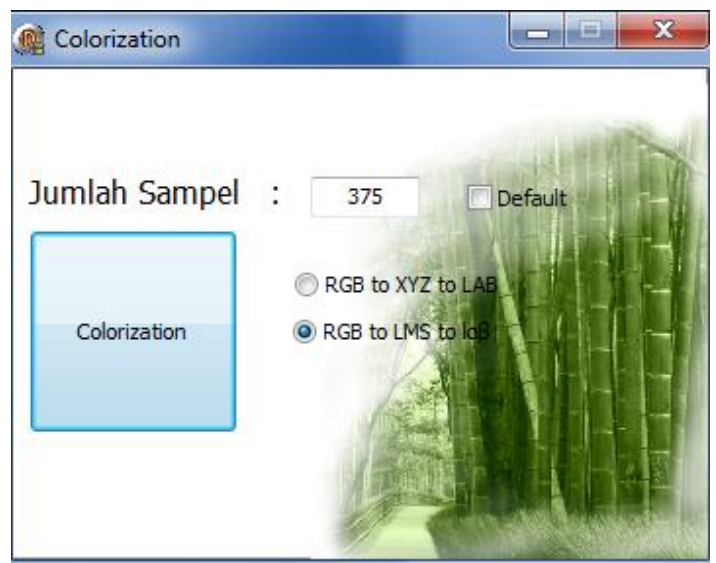

Pengujian colorization menggunakan citra inputan Zora.bmp sebagai citra warna dan matthew.bmp sebagai citra greyscale. Jumlah sampel yang digunakan sebanyak 275 pixel sampel. Gambar 7 merupakan citra inputan.

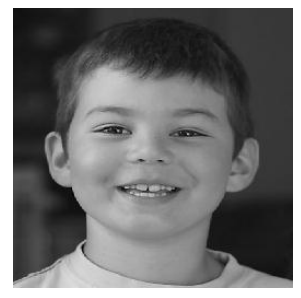

(a)

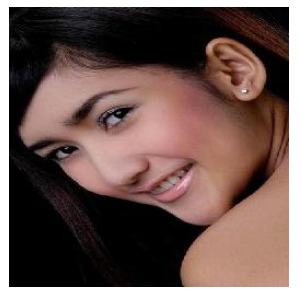

(b)

Gambar 7. Citra Input

( a. Citra greyscale, b. Citra warna )

Hasil pengolahan colorization menghasilkan citra greyscale yang sudah berwarna. Proses pewarnaan ini tidak merubah tekstur dari citra greyscale. Pada citra yang dihasilkan memiliki warna dominan coklat, ini didasarkan atas citra warna yang digunakan sebagai citra sampel memiliki warna yang dominan coklat. Hasil proses colorization dapat dilihat pada Gambar 8 .

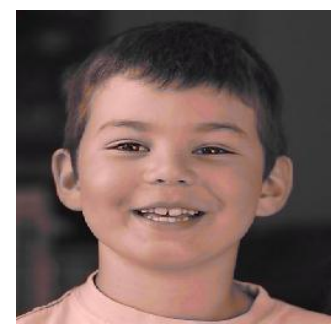

Gambar 8. Citra Output 


\subsubsection{Pengujian Image Sequences}

Proses image sequences merupakan pengembangan dari proses colorization. Pengujian image sequences menggunakan 4 buah citra inputan, yaitu 3 buah citra warna dan 1 buah citra greyscale. Seperti halnya dalam proses colorization, dalam proses image sequences user menginputkan jumlah pixel yang akan digunakan. Jumlah sampel disini adalah banyaknya jumlah sampel pixel warna yang diambil di setiap citra input warna.

Pengujian image sequences menggunakan citra input bamboo.bmp sebagai citra greyscale. Sedangkan untuk citra warna yang digunakan adalah peckham_lake.bmp, fleur2.bmp dan rumput.bmp. Citra input dapat dilihat pada Gambar 9.

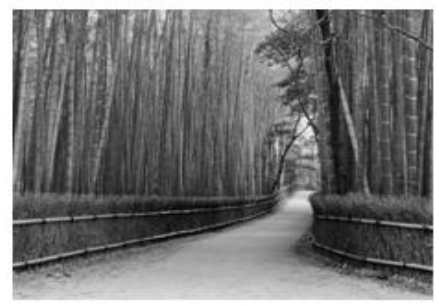

(a)

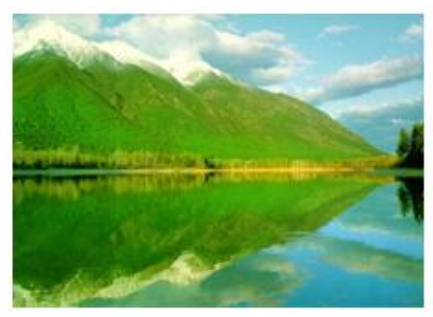

(b)

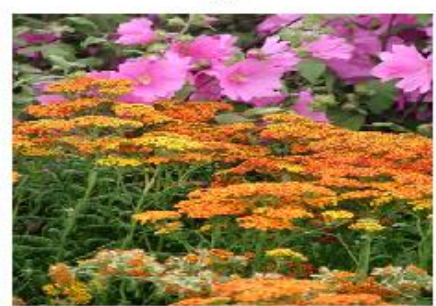

(c)

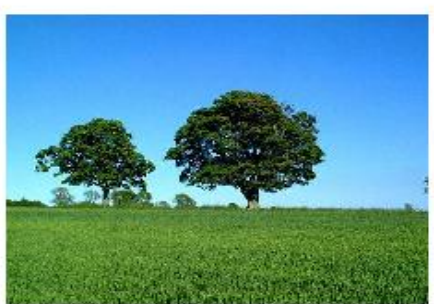

(d)

Gambar 9. Citra Input

(a. Citra greyscale, b.Citra warna 1, c.Citra warna 2, d. Citra warna 3)

Pewarnaan citra greyscale dengan menggunakan proses image sequences menghasilkan 3 buah citra utma, adapun 3 bauh citra utama tersebut dapat dilihat pada Gambar 10-a, Gambar 10-e, dan Gambar 10-i. Dengan menerapkan algoritma blending 25:75, blending 50:50, dan belnding 75:25 maka menghasilkan 12 citra. Gambar 10-b sampai dengan Gambar 10-d merupakan citra hasil blending antara Gambar 10-a dan Gambar 10-e. Gambar 10-f sampai dengan Gambar 10-h merupakan citra hasil blending 
antara Gambar 10-e dan Gambar-10-i. Sedangkan gambar 10-j samai dengan Gambar 10-f merupakan citra hasil blending Gambar 10-I dan Gambar 10-a.

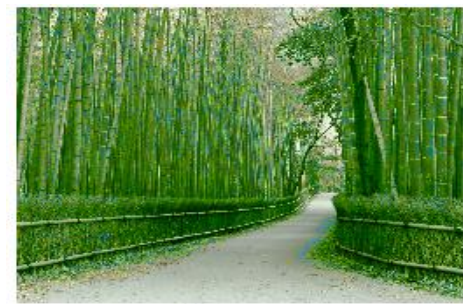

$10-\mathrm{a}$

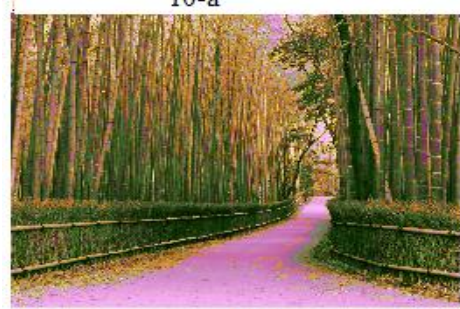

$10-d$

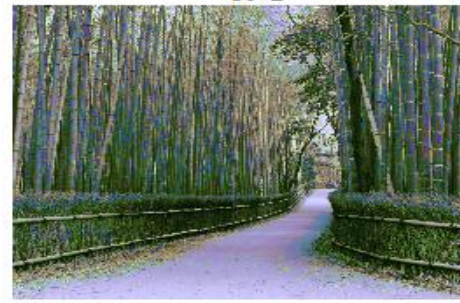

$10-\mathrm{g}$

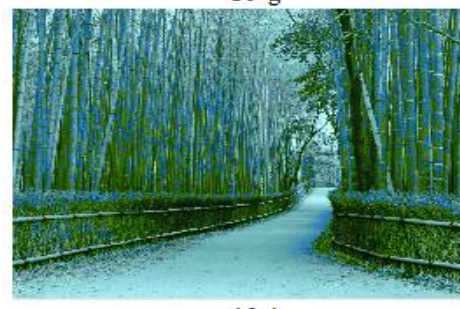

$10-\mathrm{j}$

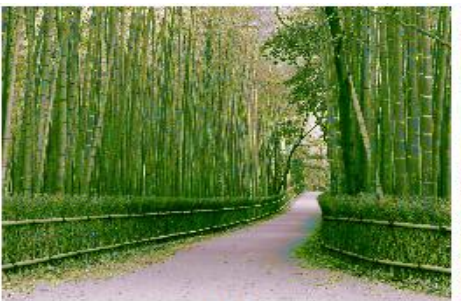

$10-b$

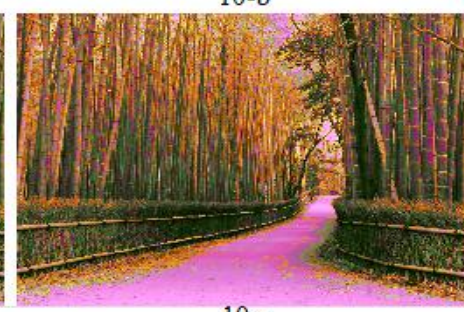

$10-\mathrm{e}$

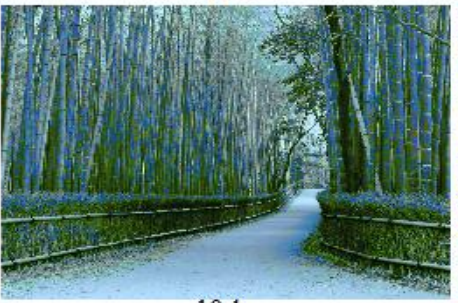

$10-\mathrm{h}$

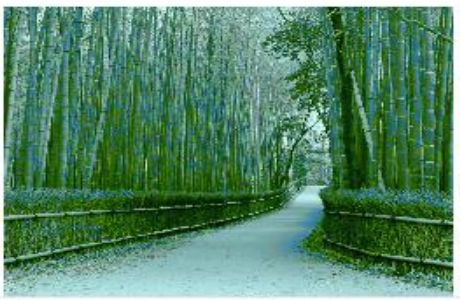

$10-\mathrm{k}$

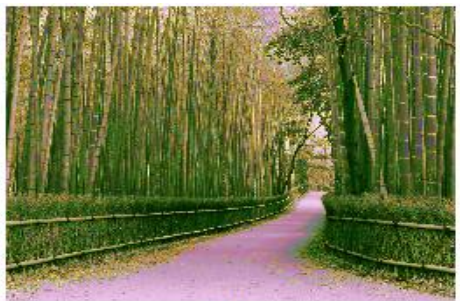

$10-c$

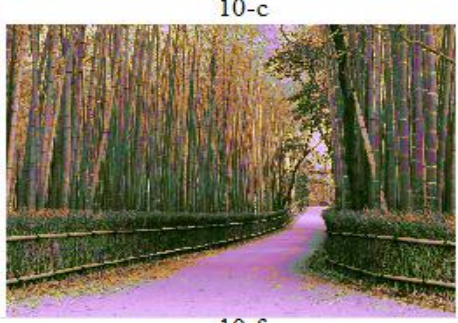

$10-f$

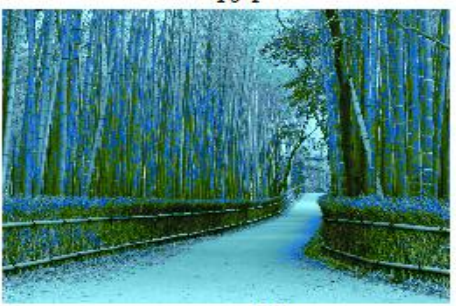

$10-\mathrm{i}$

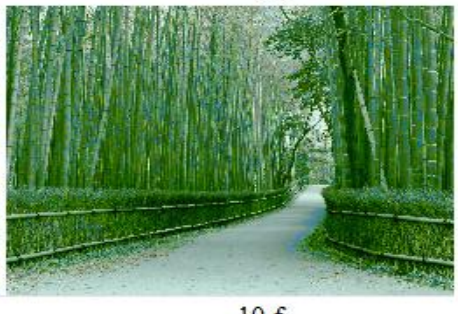

Gambar 10. Citra Output

\section{PENUTUP}

\subsection{Simpulan}

Berdasarkan penelitian yang telah dilakukan yaitu "Pengembangan Aplikasi Citra Digital untuk Mengubah Citra Greyscale Menjadi Citra Berwarna” yaitu 1) Kesesuaian sistem dalam melakukan proses pewarnaan sangat ditentukan oleh citra input yang digunakan. Semakin dekat tingkat kecerahan warna antara kedua buah citra input, maka 
ISSN 2089-8673

Jurnal Nasional Pendidikan Teknik Informatika (JANAPATI)

Volume 2, Nomor 1, Maret 2013

peluang keberhasilan sistem dalam melakukan proses pewarnaan menyerupai aslinya semakin besar., 2) Kecepatan dalam pewarnaan citra greyscale ditentukan oleh ukuran citra yang diinputkan. Semakin besar ukuran citra maka waktu yang dibutuhkan akan semakin lama, begitu juga sebaliknya semakin kecil ukuran citra maka waktu yang dibutuhkan akan semakin sedikit, 3) Dengan adanya penambahan algoritma blending, citra output yang dihasilkan akan semakin beragam sehingga user mendapat pilihan citra output yang beragam.

\subsection{Saran}

Sesuai dengan penelitian "Pengembangan Aplikasi Citra digital Untuk Mengubah Citra Greyscale Menjadi Citra Berwarna”, penelitian menyarankan untuk pengembangan yang dapat dilakukan adalah sebagai berikut: 1) Format file citra yang mampu ditangani oleh perangkat lunak pewarnaan citra greyscale tidak hanya file bmp tetapi lebih beragam seperti JPEG, GIF dan lain-lainya, 2) Adanya pengembangan algoritma yang digunakan sehingga waktu yang diperlukan dalam melakukan proses pewarnaan semakin sedikit, 3) Adanya perbaikan dalam algoritma pencocokan warna sehingga nantinya ketika menemukan citra greyscale yang memiliki kerapatan tingkat kecerahan warna yang kecil dapat diatasi.

\section{DAFTAR PUSTAKA}

Crane, Randy. 1997. A Simplified Approach to Image Processing. New Jersey: Prentice-Hall.

Dewi, Lilyana. 2003. Perencanaan Dan Pembuatan Aplikasi Untuk Transfer Warna Ke Gambar Greyscale Dengan Metode Global Image Matching. . Skripsi (diterbitkan). Teknik Informatika S1, Universitas Kristen Petra.

Erik Reinhard, Erum Arif Khan. 2008. Color Imaging Fundamentals and Applications. Wellesley,Massachusetts: A K Peters, Ltd.

Forsyth, David, Jean Ponce.2008. Computer Vision A Modern Approach. New Jersey: Prentice-Hall.

Gunung Rinjani, Ni Made Ayu. 2011. Studi Implementatif Digitalisasi Dan Restorasi Citra Digital Lontar Kuno Bali. Skripsi (tidak diterbitkan). Jurusan Pendidikan Teknik Informatika, Undiksha Singaraja. 
ISSN 2089-8673

Jurnal Nasional Pendidikan Teknik Informatika (JANAPATI)

Volume 2, Nomor 1, Maret 2013

Munir, Rinaldi. 2004. Pengolahan Citra Digital dengan Pendekatan Algoritmik. Bandung: Infomatika.

Putra, Darma. 2010. Pengolahan Citra Digital. Yogyakarta: Andi.

Reinhard, Erik. 2001. "Color Transfer Between Images". http://www.thegooch.org/Publications/PDFs/ColorTransfer.pdf. (diakses tgl 26 Nopember 2011).

Wales, Jimmy "BMP File Format". http://en.wikipedia.org/wiki/BMP file format (diakses tgl 26 Nopember 2011). 